\title{
DETERMINANTS OF THE NONPERFORMING LOANS OF NIGERIAN DEPOSIT MONEY BANKS
}

\author{
Wasiu Abiodun Sanyaolu**, Trimisiu Tunji Siyanbola² and Hafeez Babatunde Makinde 3 \\ 'Department of Accounting, Crescent University, Abeokuta, Ogun State, Nigeria \\ ${ }^{2}$ Department of Accounting, Babcock University, llishan Remo, Ogun State, Nigeria \\ 3Department of Business and Finance, Crescent University, Abeokuta, Ogun State, Nigeria
}

\begin{abstract}
Credit risk is one of the biggest challenges banks in Nigeria are faced with. By implication, it is also the one with dire consequences for their operation and survival, given the fact that a series of banks' failures have significantly been brought into connection with nonperforming loans. Thus, this study examined the bank-specific and macroeconomic determinants of the nonperforming loans of the listed Deposit Money Banks (DMBs). Regression analysis involving fixed effect was adopted in order to analyze the panel data of the 10 selected deposit money banks in the period from 2008 to 2017. The findings show that the capital adequacy ratio, the size and the loans-to-total-assets ratio negatively and significantly affect nonperforming loans, whereas profitability and age were found to significantly but positively influence nonperforming loans of the Nigerian deposit money banks. More so, the liquidity ratio negatively, but insignificantly, affects nonperforming loans. However, not a single macroeconomic variable exerts a significant effect on nonperforming loans. The study recommends that banks should always deploy strategies for credit risk management by taking cognizance of the bank-specific and economic determinants of the nonperforming loans.
\end{abstract}

Keywords: bank-specific indicators, deposit money banks, macroeconomic indicators, fixed effect and nonperforming loans

\section{INTRODUCTION}

In the majority of the world's developing economies, like Nigeria, banks serve as the agent of economic transformation by pooling and channeling idle and unproductive surplus economic resources

* Correspondence to: W. A. Sanyaolu, Department of Accounting, Crescent University, Abeokuta, Ogun State, Nigeria; e-mail: abbeysanyaolu15@yahoo.com into productive investment through financial intermediation. They do this by providing a formal arrangement which facilitates the movement of economic resources from the surplus end (i.e. savers) to the deficit end (i.e. investors), where they are needed for investment. In other words, the efficiency of the banking sector is a significant factor for increasing the volume of investment in an economy (Yüksel, Mukhtarov \& Mammadov, 2016). According to G. 
Chabakauri and B. Y. Han (2016), financial markets are also important, essentially for the following two reasons: first, they create a channel for risk sharing; second, they provide a mechanism for the efficient allocation of assets among investors. Financial services provided by the financial market, which banks are an integral part of, are therefore seen as catalysts for economic growth and their subsequent development.

Credit creation by banks in developing economies like Nigeria remains their main income-generating activity. A bank's ability to create and legitimate a new loan, therefore, depends to a certain extent on the magnitude of the deposit liability they are able to pool from savers. Channeling this deposit to a loan imposes a risk on both the bank and the depositors. Of all the risks that banks are confronted with, credit risk is the most popular and has the most significant disastrous consequence on banks' operations and stability. This claim is further buttressed by $\mathrm{M}$. Koju, R. Koju and S. Wang (2018), who opine that nonperforming is the major cause of banks' distress and financial vulnerability on the global financial market. The other risks that banks are exposed to include market risk, interest risk, exchange-rate risk and operational risk.

Credit risk refers to a risk arising from a failure of a borrower under the loan repayment obligation to fulfill the obligation of the payment of the principal amount of the loan and interest thereon as they fall due. The Basel Committee on Banking Supervision (2001) defines credit risk as the probability of losing an outstanding loan amount partially or wholesomely due to different credit events (default risk). This implies that the banks more exposed to credit risk have a higher tendency to distress and failure. It has been adjudged by McKinsey and Company that of all the risks banks are confronted with credit risk remains the most prominent, as it accounts for almost $60.0 \%$ of the entire risk exposure, whereas market and operational risks were found to account for $20.0 \%$ of such risk each, respectively. According to L. Agnello and R. M. Sousa (2011), concern for risk management in banks is sustained as a result of the negative consequence that bank distress may have on the economy.

The need to prevent bank failure is now occupying the central attention of the major players and regulators on the financial market, oriented towards banks' risk management arising from the unfavorable consequence that nonperforming loans have had, as well as those they may have, on banks' operations and survival, most especially so in developing economies (such as Nigeria), where banks are vulnerable to the credit risk originating from the information asymmetry preventing banks from being able to assess the borrower's ability to fulfill their obligation to repay the loan and their inability to properly assess the viability of the project for which the customer is applying for a loan with the bank and its monitoring. There are also other factors, such as paucity on the part of the bank to institute and enforce an effective credit risk management system and fraudulent practices on the part of various loan officers and managers.

The volatile and turbulent macroeconomic conditions evident in Nigeria have also hindered customers' ability to repay a loan amount as their business profitability has greatly been hindered by the unfriendly economic conditions prevalent in the country. Therefore, effective and efficient credit risk management is becoming imperative for the banks that wish to reduce the efficacy of nonperforming loans in their turbulent and ever-volatile operating environment as this has a serious implication for their financial performance, stability and going concern. According to M. Psillaki, I. E. Tsolas and D. Margaritis (2010), efficient risk management practices will help to uphold the business viability and profitability of banks and also support the systemic stability and efficient allocation of capital in the economy.

The bank-specific, as well as macroeconomic, variables may affect their exposure to credit risk. Bank-specific variables are those factors that are considered as being special to banks and within their control axis. Those variables, which are considered in this study, include profitability, liquidity, capital adequacy, age, loans-to-total assets and the size. On the other hand, macroeconomic variables are those that affect the 
aggregate economy and, by implication, all firms, regardless of the industry they may belong to, which they do not have control of. Those macroeconomic indicators which are considered in this study are the interest rate, the inflation rate and the gross domestic product growth rate, arising from the unfavorable consequence which nonperforming loans may have on banks' operations, as well as the need to effectively and efficiently manage risk. It is interesting to conduct an investigation into the different factors that may influence nonperforming loans in a bank-based economy like Nigeria.

The available literature has revealed that many researchers from both developed and developing economies have explored different areas of nonperforming loans. Only few studies, however, have been conducted on the bank-specific and macroeconomic determinants of nonperforming loans in Nigeria. The studies carried out by (Alshatti, 2015; Kajola, Adedeji, Olabisi \& Babaolu, 2018; Okere, Isiaka \& Ogunlowore, 2018) focused on nonperforming loans and profitability.

Therefore, this study was motivated by the paucity of empirics on the bank-specific and macroeconomic determinants of the nonperforming loans of the Nigerian listed deposit money banks. Based upon this, the study intends to reduce the knowledge gap to the barest minimum. The specific goals of the study include the examination of the effect of profitability on the nonperforming loans of the Nigerian deposit money banks, an analysis of the effect of liquidity on the nonperforming loans of the Nigerian deposit money banks, an analysis of the effect of capital adequacy on the nonperforming loans of the Nigerian deposit money banks, the investigation of the effect of age on the nonperforming loans of the Nigerian deposit money banks, the evaluation of the effect of the loans-to-total-assets ratio on the nonperforming loans of the Nigerian deposit money banks, an analysis of the effect of the size on the nonperforming loans of the Nigerian deposit money banks, the examination of the effect of economic growth on the nonperforming loans of the deposit money banks in Nigeria, an analysis of the effect of inflation on the nonperforming loans of the Nigerian deposit money bank, and assessing the issue of the effect of the interest rate on the nonperforming loans of the Nigerian deposit money banks.

The conceptual, theoretical and empirical reviews form the basis of the second part of the paper. In Section Three, the methodology employed in the study is discussed, whereas the research findings are presented in Section Four. The findings of the study are discussed in Section Five. The conclusion and recommendations arising from the findings are given in Section Six.

\section{LITERATURE REVIEW}

In the study, a total of nine variables are used as a surrogate for the determinants of the nonperforming loans of the Nigerian deposit money banks. These are referred to as the independent variables, and the same are discussed below.

\section{Conceptual review}

'Nonperforming loans' is the only dependent variable for this study. It is a measure of a bank's credit risk, computed as the nonperforming-loans-to-total-loans ratio. Researchers as A. S. Messai and F. Jouini (2013) and S. O. Kajola et al (2018) used it to proxy credit risk in their studies.

Profitability is the ability of a business to earn net revenue in excess of its cost. A profit is very important in the business affairs of any profit-oriented outfit. Also, a business must make a profit in order for it to grow. Different profitability measures were used by the researchers in the prior literature in order to proxy profitability. The common barometers used in measuring it are Return on Asset, Return on Equity, Return on Capital Employed, the absolute value of Profit Before Tax and the absolute value of Profit After Tax. For the purpose of this study, ROA is used for the surrogate for profitability. This is premised on its ability to measure the efficiency of management with respect to the resources at their disposal. The relationship between profitability and nonperforming 
loans can be viewed from the two perspectives: first, the banks that wish to be profitable may grant more loans, thus achieving a high credit default rate, on the one hand, and second, the banks that are profitable may grant more loans to their borrowers, on the other. The hypothesis presented in the study is stated as:

H1: Profitability has no significant effect on the nonperforming loans of the Nigerian listed DMBs.

Liquidity refers to a bank's ability to fulfil its shortterm maturing obligations. Liquidity is a variable of interest to depositors and the bank's creditors as it shows the extent to which the bank is able to fulfill its obligation of paying out their deposits upon request. Conceptually, liquidity is expected to negatively affect nonperforming loans, due to a tradeoff between the amount of the liquidity kept by the bank and the amount of the loan they are able to advance to the borrowers. The study hypothesizes that:

$\mathrm{H} 2$ : Liquidity management has no significant effect on the nonperforming loans of the Nigerian listed DMBs.

Capital adequacy refers to the ratio of a bank's primary capital to its total assets. The higher the capital, the better it is in terms of strength. The banks that are highly capitalized have a low tendency for nonperforming loans, whereas there is a reverse case when undercapitalized banks are in question. Low capitalization is an indicator of moral hazard. The following hypothesis is formulated:

H3: Capital adequacy has no significant effect on the nonperforming loans of the Nigerian listed DMBs.

In this study, age refers to the number of the years Nigerian banks have been listed on the stock exchange, meaning the year in which a bank began to operate in a sophisticated form. Bank age is expected to have a negative effect on nonperforming loans, given the fact that their experience arises from the number of the years they have been operating may help to prevent credit risk. Based upon this expectation, the hypothesis reads as follows:
H4: Age has no significant effect on the nonperforming loans of the Nigerian listed DMBs.

Loans-to-total-assets is expected to affect the degree of nonperforming loans. A bank with a high loans-tototal-assets ratio will have a high credit default rate. In this direction, the study hypothesizes as follows:

H5: Loans-to-total-assets has no significant effect on the nonperforming loans of the Nigerian listed DMBs.

In terms of the size, bigger banks are effective in controlling the problem of nonperforming loans, because they have advanced technologies and skilled manpower to tactfully handle moral hazard and agency problems (Salas \& Saurina, 2002; Ranjan \& Dhal, 2003). In addition, big banks collect ample relevant information related to borrowers, which enables them to take correct lending decisions. Contrarily, the motive to achieve a monopoly profit may prompt bigger banks to extend their operations to risky sectors, thus propelling a high rate of bad loans and causing market failures (Shleifer \& Vishny, 2010; Ratnovski, 2012; Gennaioli, Shleifer \& Vishny, 2013). The hypothesis reads as follows:

H6: The bank size has no significant effect on the nonperforming loans of the Nigerian listed DMBs.

Economic growth is mostly measured in terms of the gross domestic product. During the period of an increased gross domestic product, banks may issue more loans and advances to their customers. The relationship between economic growth and nonperforming loans is expected to be negative. During this period, borrowers are able to fulfill their obligations due to favorable economic conditions; banks are able to make credit conditions conducive for investment. The study hypothesized as follows:

H7: Economic growth has no significant effect on the nonperforming loans of the Nigerian listed DMBs. 
During inflation, borrowers may demand more loans so as to finance their consumption of goods and services. This may push the banking sector to grant more loans and charge high interest on borrowed funds. Due to the economic hardship prevalent in the economy, borrowers may not be able to fulfill their contractual obligation of payment of interest and the principal due.

H8: Inflation has no significant effect on the nonperforming loans of the Nigerian listed DMBs

One of the contributing factors to nonperforming loan is the lending rate. The higher the rate charged by commercial banks on amount of loan they grant, the higher the rate of default and vice versa.

H9: Interest rate has no significant effect on nonperforming loan of The Nigerian listed DMBs.

\section{THE THEORETICAL FRAMEWORK}

Information asymmetry theory was proposed by G. A. Akerlof (1970) and J. E. Stiglitz and A. Weiss (1981). This theory argues that there is an information difference between the bank and the borrower approaching the bank for a loan as to the risk of the project that he/she wants to obtain the loan for in order to finance it. In this case, the borrower has more information than the bank and may prey on this to influence the bank to take a suboptimal course of action, which the bank would not be able to take if it had equal information about the project to finance as the borrower does. In this case, there is a likelihood for adverse selection and moral hazard (Matthews \& Thompson, 2008). Therefore, the bank can bridge this information gap in the following manners: having a long-term relationship with the borrower before granting him/her a loan, information sharing and, ultimately, monitoring the project.

Agency theory states that there are two parties in a formal corporation, i.e. shareholders and managers. Shareholders are the owners of the company, while managers are those statutorily employed for the day-to-day management of the business affairs of the corporation. Shareholders entrust the appointed managers with resources and the managers act on their behalf as agents. Managers are expected to act in the best interest of shareholders, such as by making decisions that will maximize shareholders' wealth. In practice, however, managers may pursue the strategies and courses of action that are in their (managers') own best interest as against that of the principals. In order to prevent this agency problem, managers are monitored from time to time. This monitoring further imposes an agency cost on the management, such as managers' emoluments and an audit fee. This theory is relevant to this study, as managers may attempt to increase the loan they grant to their borrowers without taking into consideration the needed modalities for granting loans, as managers are remunerated based upon their ability to earn more of an accounting profit, not a cash profit, which may, therefore, increase the efficacy of nonperforming loans in banks.

Financial intermediation theory was proposed by F. Allen and A. M. Santomero (1997). Financial institutions serve as a fund mobilization agent between the deficit economic unit and the surplus unit. The theory tries to emphasize the fund mobilization agency service by serving as an intermediary between fund lenders and fund borrowers. According to D. Diamond (1984), banks are able to effectively monitor borrowers, thus playing the delegated monitoring role. This delegated monitoring helps reduce market failure on the financial market.

\section{RELATED EMPIRICAL STUDIES}

S. I. Kasana and Q. M. Naveed (2016) focused on a total of 26 commercial banks in Pakistan from 2007 to 2013. Capital adequacy and loan loss provision growth were found to exert a significant and positive influence on credit risk, while the significant negative influence of the growth rate of the GDP, the advances growth rate and return on assets (ROA) was found to exist on credit risk. The study could not, however, 
establish the significant influence of operating inefficiency, the loan-deposit ratio, the growth rate of the interest rate and the size on credit risk.

EL-M. J. Gambo, A-R. Ahmad and I. Muhammad (2017) focused on the examination of the determinants of the nonperforming loans of the Nigerian deposit money banks. A positive significant relationship was found to exist between nonperforming loans and the loans-to-deposits ratio and the bank size, whereas the capital adequacy ratio and inflation revealed a positive insignificant relationship and return on assets had a negative insignificant relationship with the nonperforming loan rate. The study conducted by V. Makri and K. Papadatos (2014) is in contrast with the findings of EL-M. J. Gambo et al (2017).

W. Waemustafa and S. Sukri (2015) examined the bankspecific and macroeconomic determinants of credit risk in Islamic and commercial banks in Malaysia. The study employed multivariate regression on the data obtained on a total of 13 Islamic and 15 conventional banks. The study established a significant influence of financing the risky sector, regulatory capital (REGCAP) and the Islamic Contract on credit risk in the Islamic banks, while simultaneously loan-loss provision, the debt-to-total-assets ratio, REGCAP, the size, earnings management and liquidity were found to exert a significant influence on the credit risk of commercial banks. The study could not find a significant influence of macroeconomic determinants, such as the GDP and the output gap, on credit risk; inflation and M3, however, were found to have a significant influence on the credit risk of both banks.

T. R. Mpofu and E. Nikolaidou (2018) examined credit risk determinants in Sub-Saharan Africa by using a dynamic panel model for the period from 2000 to 2016. The results showed that an increase in the real GDP growth rate had a statistically and economically significant reducing effect on the nonperforming loans-to-total-gross-loans ratio. Furthermore, the inflation rate, domestic credit to the private sector by banks as a percentage of the GDP, trade openness, the VIX as the global volatility prosy, and the 2008/2009 global financial crisis all had a positive and significant influence on NPLs.

L. Trenca and D. Bozga (2018) focused on the factors that determine banks' credit risks in Europe. The panel data for 70 commercial banks across 13 European countries from Q12005 to Q42011were used. The result showed a positive effect of the capital adequacy ratio, the unemployment rate, the inflation rate, the government debt, the bank concentration on nonperforming loans, whereas the GDP growth was found to exert a negative influence on nonperforming loans.

J. Shkodra and H. Ismajli (2017) used the data of seven commercial banks in Kosovo* for the period from 2006 to 2015 and found a significant influence of profitability (ROE and ROA), inefficiency (IE), the loans-to-deposit ratio (LDR), credit growth (CG) and the deposit rate (DR). The study, however, could not find any significant effect of the solvency (SR) and credit rates $(\mathrm{CR})$ on the credit risk of Kosovo* banks.

Based upon the examination of the nonperforming loan determinants in the Jordanian banking sector, K. S. Rajha (2017) found the existence of a significant positive influence of a period lag on the nonperforming-loans-to-total-assets ratio, while the size was found not to significantly influence nonperforming loans. Economic growth and inflation as macroeconomic determinants were found to exert a significant negative influence on nonperforming loans; in the same vein, the global financial crisis was found to significantly and positively influence nonperforming loans.

A. S. Messai and F. Jouini (2013) examined the microand macro-variables that are likely to influence nonperforming loans, and they did it on a sample of 85 banks in Italy, Greece and Spain for the data span a period of time from 2004 to 2008. The study found the negative influence of the GDP growth and banks' profitability, and the positive influence of the unemployment rate, a loan loss reserve to total loans and the real interest rate. 
U. Murthy, N. M. Kamil, P. A. Mariadas and D. Devi (2017) conducted a study by using the primary data obtained from a questionnaire distributed to the respondents of the Selangor State of Malaysia. The findings of the study show evidence in support of the significant influence of the economic condition, consumers' income and bank interest, while no significant effect of the standard of living on nonperforming loans could be established.

In Nigeria, O. Akinlo and E. Mofoluwaso (2014) employed the Johansen Juselius Co-Integration and Error Correction Model to analyze the data obtained from the Central Bank of Nigeria's Statistical Bulletin for the period from 1981 to 2011 and found that economic growth negatively influenced nonperforming loans, whereas the unemployment rate, crediting the private sector and the exchange rate were found to positively affect nonperforming loans in the long run. A short-term analysis shows that credits to the private sector, the exchange rate, the lending rate and the stock market index are the key determinants of nonperforming loans.

A. Ikram, Q. Su, F. Ijaz and M. Fiaz (2016) conducted an investigation of the bank-specific and macroeconomic determinants of nonperforming loans in Pakistan. The goal of the study was achieved via the delivery of a questionnaire to credit analysts' bankers of the 42 branches of nine commercial banks. Data analysis was performed by a selective descriptive analysis and the Pearson chi-square. The study found that NPLs are significantly influenced by a credit policy (the nature of the contract), the age of the bank branch and the term of the loan, while SMEs' repayment capacity, the nature and the valuation of collateral do not significantly relate to NPLs. V. Swamy (2012) found a significant positive effect of profitability on the nonperforming loans of banks. V. Makri and K. Papadatos (2014) found a significant negative effect of the capital adequacy ratio on the credit risk of Greek banks.

F. O. Awuor (2015) found a significant positive effect of profitability on the nonperforming loans of banks, which was corroborated by V. Swamy (2012).

\section{THE RESEARCH METHODS AND PROCEDURE}

The study adopted ex post facto research, which is characterized by the quantitative attribute of data. The ex post facto research design is the design used when data related to a past event are used in a study. The population of the study consists of all the 15 quoted deposit money banks. The chosen sample size is 10 , which represents $67 \%$ of the population of the study, thus satisfying the sampling criteria. The size of the banks was considered when choosing the sample. The banks include GT Bank Plc, UBA Plc, Access Bank Plc, Zenith Bank Plc, First Bank Plc, Sterling Bank Plc, Diamond Bank Plc, Fidelity Bank Plc, Wema Bank Plc and Unity Bank Plc. The data for the study were obtained from a secondary source by extracting relevant ratios from the annual reports and accounts of the 10 sampled banks for the considered periods from 2008 to 2017.

\section{Model specification}

Generally, the model is specified as follows:

$$
Y=f(X)
$$

where:

$Y=$ the nonperforming loans (the dependent variable), and

$X=$ the determinants (the independent variable).

Therefore, the model is specified as follows:

$$
\begin{aligned}
& N P L R=F(R O A, L I Q, C A R, A G E, L O T A, S Z, \\
& G G D P, I N F, I N T)
\end{aligned}
$$

The model is re-presented in the model 2 in econometrics terms:

$$
\begin{aligned}
& N P L R_{i t}=\beta_{0}+\beta_{1} R O A+\beta_{2} L I Q R+\beta_{3} C A R_{i t}+ \\
& \beta_{4 i t} A G E_{i t}+\beta_{5} L O T A \beta_{6} S Z_{i t}+\beta_{7} G G D P_{i}+ \\
& \beta_{8} I N F_{i}+\beta_{9} I N T_{i}+e_{i t}
\end{aligned}
$$

where:

$N P L R_{i t}=$ the nonperforming loans of the bank $i$ in the period $t, R O A_{i t}=$ the return on asset of the bank $i$ in the period $t, L I Q R_{i t}=$ the liquidity ratio $i$ in the period 
$t, C A R i t=$ the capital adequacy ratio of the bank $i$ in the period $\mathrm{t}, A G E_{i t}=$ the age of the bank $i$ in the period $t, L_{\text {OTA }}=$ the loans-to-total-assets ratio of the bank $i$ in the period $t, S Z_{i t}=$ the size of the bank $i$ in the period $t, G G D P_{t}=$ the growth of the gross domestic product in the period $t, I N F_{t}=$ the inflation rate in the period $t$, and $I N T_{t}=$ the interest rate in the period $t$;

$\beta_{0}=$ Constant;

$\beta_{1}-\beta_{9}=$ the coefficient of the independent variable;

$e_{i t}=$ the error term.

\section{The description and measurement of the variables}

Table 1 below presents the description of the variables of the study.

Table 1 The measurement of the variables

\begin{tabular}{|c|c|c|c|}
\hline Variable & $\begin{array}{l}\text { Acro- } \\
\text { nym }\end{array}$ & Measure & $\begin{array}{l}\text { Expe- } \\
\text { cted } \\
\text { effect }\end{array}$ \\
\hline \multicolumn{4}{|c|}{ Dependent variables } \\
\hline $\begin{array}{l}\text { Nonperforming } \\
\text { loans }\end{array}$ & NPLR & $\begin{array}{l}\text { Nonperforming } \\
\text { loans/total loans }\end{array}$ & \\
\hline \multicolumn{4}{|c|}{ Independent variables } \\
\hline Profitability & ROA & $\begin{array}{l}\text { Profit after tax/ } \\
\text { total assets }\end{array}$ & + \\
\hline Liquidity & LIQR & $\begin{array}{l}\text { Cash + treasury } \\
\text { bills/total deposits }\end{array}$ & - \\
\hline $\begin{array}{l}\text { Capital } \\
\text { adequacy }\end{array}$ & CAR & $\begin{array}{l}\text { Equity capital/total } \\
\text { assets }\end{array}$ & - \\
\hline Age & AGE & $\begin{array}{l}\text { Natural log of the } \\
\text { listing years }\end{array}$ & - \\
\hline $\begin{array}{l}\text { Loan to total } \\
\text { assets }\end{array}$ & LOTA & $\begin{array}{l}\text { Total loans/total } \\
\text { assets }\end{array}$ & + \\
\hline Size & LASSET & $\begin{array}{l}\text { Natural logarithm } \\
\text { of total assets }\end{array}$ & + \\
\hline $\begin{array}{l}\text { Economic } \\
\text { growth }\end{array}$ & GDPG & $\frac{G D P_{t}-G D P_{t-1}}{G D P_{t-1}}$ & - \\
\hline Inflation rate & INFR & $\begin{array}{l}\text { Percentage of the } \\
\text { inflation rate }\end{array}$ & + \\
\hline Interest rate & INTE & $\begin{array}{l}\text { Percentage of the } \\
\text { interest rate }\end{array}$ & + \\
\hline
\end{tabular}

Source: Authors

\section{RESEARCH FINDINGS}

The result of the descriptive statistics of the variables used in the study is shown in Table 2. Table 2 shows that ROA has a mean value of 0.010 and varies from the minimum value of -0.105 and the maximum value of 0.120 . LIQ has a mean value of 0.211 , with the minimum of 0.012 and the maximum of 0.622 . CAR has a mean value of 0.143 , ranging from -0.105 to 0.804 . The average age of the sampled banks is 18.160 , and ranges from the minimum of 0.000 to the maximum of 47 . The NPLR is averaged 0.099 , and ranges from 0.023 to 0.970 . LOTA has a mean value of 0.516 , with the minimum of 0.032 and the maximum of 4.538 . LASSET has a mean value of 20.74, and ranges from 17.876 to 22.416 . INTE has a mean value of 0.165 , the minimum being 0.140 and the maximum being 0.184 . INFR is averaged 0.119 , the minimum being 0.080 and the maximum being 0.184. Finally, the GDPG is averaged 0.133 , with the minimum value of -0.053 and the maximum value of 0.830 .

\section{Correlation}

The correlation matrix presented in Table 3 below reveals that liquidity, capital adequacy, age, loans to total assets, the size, the interest rate, the inflation rate and the gross domestic product growth rate are all positively correlated with profitability, whereas only nonperforming loans have a negative correlation with it. No coefficient of the variables exceeds the value of 0.8 , either, which is implicative of the fact that there is no co-linearity problem.

\section{Regression}

Following the prior empirical investigations conducted by V. Swamy (2012); A. S. Messai and F. Jouini (2013); V. Makri and K. Papadatos (2014), this study estimated multiple regression analysis by using the Fixed Effect Least Squares (FELS) and Random Effects Generalized Least Squares (REGLS) techniques. The results are presented in Table 4 below. The result of the Hausman test shows that the fixed effect is appropriate. Profitability was found to 
Table 2 The summary of the descriptive statistics

\begin{tabular}{l|cccccccccc}
\hline & NPLR & ROA & LIQ & CAR & AGE & LOTA & LASSET & INTE & INFR & GDPG \\
\hline Mean & 0.099 & 0.010 & 0.211 & 0.143 & 18.160 & 0.516 & 20.74 & 0.165 & 0.119 & 0.133 \\
Median & 0.050 & 0.014 & 0.191 & 0.144 & 15.00 & 0.495 & 20.74 & 0.165 & 0.119 & 0.133 \\
Maximum & 0.970 & 0.120 & 0.622 & 0.804 & 47.00 & 4.538 & 22.416 & 0.184 & 0.165 & 0.830 \\
Minimum & 0.023 & -0.105 & 0.012 & -0.402 & 0.000 & 0.032 & 17.876 & 0.140 & 0.080 & -0.053 \\
Std. Dev & 1777.069 & 194.995 & 9.024 & 1661.506 & 11.857 & 24790.3 & 4.407 & 6.021 & 5.558 & 198.97 \\
\hline Observations & 100 & 100 & 100 & 100 & 100 & 100 & 100 & 100 & 100 & 100 \\
\hline
\end{tabular}

Source: Authors

Table 3 The correlation matrix

\begin{tabular}{|c|c|c|c|c|c|c|c|c|c|c|}
\hline & ROA & LIQ & CAR & AGE & NPLR & LOTA & LASSET & INTE & INFR & GDPG \\
\hline $\mathrm{ROA}$ & 1.000000 & & & & & & & & & \\
\hline LIQ & 0.253706 & 1.00000 & & & & & & & & \\
\hline CAR & 0.660986 & 0.12330 & 1.00000 & & & & & & & \\
\hline AGE & 0.104402 & 0.1302 & -0.119 & 1.00000 & & & & & & \\
\hline NPLR & -0.132321 & -0.370 & -0.223 & -0.122 & 1.000000 & & & & & \\
\hline LOTA & 0.416220 & -0.070 & 0.630 & 0.054 & -0.085 & 1.000000 & & & & \\
\hline LASSET & 0.253267 & 0.645 & 0.077 & 0.390 & -0.319 & -0.241 & 1.000000 & & & \\
\hline INTE & 0.064340 & -0.100 & 0.071 & -0.024 & 0.196 & 0.045 & -0.145 & 1.000000 & & \\
\hline INFR & 0.035883 & -0.104 & 0.0497 & -0.025 & 0.202 & 0.048 & -0.004 & -0.262 & 1.000000 & \\
\hline GDPG & 0.013209 & 0.094 & 0.001 & 0.051 & -0.055 & -0.025 & 0.144 & -0.680 & 0.488 & 1.000000 \\
\hline
\end{tabular}

Source: Authors

have a positive significant effect on nonperforming loans. The liquidity ratio exerts no significant negative effect on nonperforming loans. Capital adequacy shows a negative, but significant effect on nonperforming loans. Age was found to have a significant positive effect on the nonperforming loans of the deposit money banks in Nigeria. The finding related to the effect of the loans-to-total-assets ratio on nonperforming loans demonstrates the existence of a significant negative effect of the loans-to-total- assets ratio on nonperforming loans. The size was found to exert a significant negative effect on the nonperforming loans of the Nigerian deposit money banks.

As to the macroeconomics variables, the interest rate (INT) and the inflation rate individually exert no significant positive effect on nonperforming loans. Also, the GDPG exerts a positive, but insignificant influence on nonperforming loans. 
Table 4 Regression Analysis for the determinants of nonperforming loans

\begin{tabular}{|c|c|c|c|c|c|c|c|c|c|}
\hline & \multicolumn{3}{|c|}{ Pooled OLS Estimation } & \multicolumn{3}{|c|}{ Fixed Effect } & \multicolumn{3}{|c|}{ Random Effect } \\
\hline Regressors & Coeff. & t-stat. & p-val. & Coeff. & t-stat. & p-val. & Coeff. & t-stat. & p-val. \\
\hline Constant & -0.167 & -0.185 & 0.854 & 5.687 & 3.196 & 0.002 & -0.107 & -0.207 & 0.838 \\
\hline $\mathrm{ROA}$ & 0.919 & 1.243 & 0.221 & 2.474 & 3.117 & 0.003 & 0.919 & 1.371 & 0.174 \\
\hline LIQ & -0.269 & 0.142 & 0.061 & -0.282 & -1.741 & 0.086 & -0.269 & -2.115 & 0.037 \\
\hline CAR & -0.434 & 0.209 & 0.041 & -0.734 & -3.434 & 0.001 & -0.434 & -2.307 & 0.024 \\
\hline AGE & -0.001 & 0.001 & 0.418 & 0.048 & 3.364 & 0.001 & -0.001 & -0.905 & 0.368 \\
\hline LOTA & -0.003 & -0.056 & 0.956 & -0.134 & -2.264 & 0.027 & -0.003 & -0.062 & 0.951 \\
\hline SIZE & -0.018 & -0.763 & 0.448 & -0.323 & -3.568 & 0.001 & -0.018 & -0.847 & 0.399 \\
\hline INTE & 3.436 & 2.055 & 0.043 & 2.367 & 1.502 & 0.137 & 3.436 & 2.283 & 0.025 \\
\hline INFR & 1.226 & 2.107 & 0.038 & 0.853 & 1.576 & 0.119 & 1.226 & 2.341 & 0.022 \\
\hline GDPG & 0.0350 & 0.385 & 0.701 & -0.041 & -0.479 & 0.633 & 0.035 & 0.427 & 0.670 \\
\hline R-square & & & 0.283 & & & 0.481 & & & 0.283 \\
\hline Adj.R-square & & & 0.207 & & & 0.358 & & & 0.207 \\
\hline F-stat & & & 3.732 & & & 3.194 & & & 3.732 \\
\hline Prob F-stat & & & 0.0 & & & 0.000 & & & 0.000 \\
\hline Durbin Watson & & & 1.735 & & & 2.228 & & & 1.735 \\
\hline Hausman Test & 28.97 & 9 & 0.0007 & & & & & & \\
\hline
\end{tabular}

Source: Authors

The value of the F-statistics is 3.194, which is significant at a $5 \%$ significance level. This indicates the fact that all the identified determinants (i.e. the bank-specific and macroeconomic determinants) have a joint significant influence on nonperforming loans. Therefore, the hypothesis that the bank-specific and macroeconomic variables do not have a significant joint effect on the nonperforming loans of the Nigerian listed deposit money banks is rejected.

\section{THE DISCUSSION OF THE FINDINGS}

Based upon the result obtained the Fixed Effect Ordinary Least Square, profitability was found to have a positive significant effect on nonperforming loans. It may be argued that, in an attempt to attract a bigger profit, Nigerian banks often grant excessive loans, a substantial part of which may not perform. As profitability is reported on an accrual basis, it may be increasing even if the loan granted along with interest is yet to be paid. The outcome of this finding is in tandem with that obtained by V. Swamy (2012) and F. O. Awuor (2015), who found a significant positive effect of profitability on banks' nonperforming loans. Arising from this finding, the hypothesis H1, implying no significant positive effect of profitability on nonperforming loans, is therefore rejected.

The liquidity ratio was found to have no significant negative effect on nonperforming loans. This outcome is in conformity with the a priori expectation of the study. The negative effect can be justified on the ground of the fact that banks' preference for remaining liquid will negatively affect the amount they are willing to invest in loans, and, the lower the loan granted, the lower the level of nonperforming loans. This finding is in line with that obtained by W. Waemustafa and S. Sukri (2015). Arising from the said, 
the hypothesis $\mathrm{H} 2$, implying no significant negative effect of liquidity management on the nonperforming loans of the Nigerian listed deposit money banks, is therefore accepted.

Capital adequacy shows both negative and significant effects on nonperforming loans. This finding is in line with the a priori expectation of the study. It is also in line with the finding of V. Makri and K. Papadatos (2014). The hypothesis H3, implying no significant negative effect of the capital adequacy ratio on the nonperforming loans of the Nigerian listed deposit money banks, is therefore rejected.

Age was found to have a significant positive effect on the nonperforming loans of the deposit money banks in Nigeria. The logical conclusion that can be drawn from this finding is that, as banks increase in age, their loans also increase in the same order, which may suggest high nonperforming loans. Therefore, the hypothesis $\mathrm{H} 4$, implying no significant positive effect of age on the nonperforming loans of the Nigerian listed deposit money banks, is rejected.

The finding pertaining to the effect of the loans-tototal-assets ratio on nonperforming loans shows the existence of a significant negative effect of the loansto-total-assets ratio on nonperforming loans. This finding implies that the deposit money banks in Nigeria have a low loans-to-total-assets ratio, which affords them the opportunity to absorb credit risk. The finding is in contrast with that of K. S. Rajha (2017), who found a significant positive effect of the loans-to-total-assets ratio on nonperforming loans. Therefore, the hypothesis H5, implying no significant negative effect of the loans-to-total-assets ratio on the nonperforming loans of the Nigerian listed deposit money banks, is rejected.

The size was found to have a significant negative effect on the nonperforming loans of the deposit money banks in Nigeria. This finding is in consonance with the assertion by (Salas \& Saurina, 2002; Ranjan \& Dhal, 2003) that big banks have access to sophisticated technology and the needed manpower and skills to obtain necessary and sufficient information about moral hazards. This finding corroborates the result of prior studies, such as those by N. T. Duong and T. T.
Huong (2016), which found a significant negative effect of the size on nonperforming loans. Arising from this fact, the hypothesis $\mathrm{H6}$, implying no significant negative effect of the size on nonperforming loans, is therefore rejected.

As far as the macroeconomic variables are concerned, the interest rate and the inflation rate individually have no significant positive effect on nonperforming loans. Also, the growth rate experts a positive, but insignificant influence on nonperforming loans. The finding pertaining to the effect of the interest rate on nonperforming loans is in contrast with that of P. D. Louziz, A. T. Vouldis; V. L. Metaxas (2010); I. Saba, R. Kouser and M. Azeem (2012). Due to this finding, the hypothesis $\mathrm{H}$, implying no significant positive effect of the interest rate on nonperforming loans, is accepted, while the result for the influence of the inflation rate on nonperforming loans further contradicts the finding of C. F. Djiogap and A. Ngomsi (2012). The hypothesis H8, implying no significant positive effect of the inflation rate on nonperforming loans is therefore accepted. The finding as to the negative, but insignificant effect of the growth rate on nonperforming loans is in line with that of I. Saba, R. Kauser and M. Azeem (2012); B. Skarica (2013). Therefore, the hypothesis H9, implying no significant negative effect of the gross domestic product growth rate on the nonperforming loans of the Nigerian listed deposit money banks, is accepted.

\section{CONCLUSION}

The main thrust of this study was the empirical investigation of different bank-specific and macroeconomic determinants of the nonperforming loans of a total of 10 listed deposit money banks in Nigeria for the period from 2008 to 2017. The main finding of this study is that $35.8 \%$ of variations in the nonperforming loans is accounted for by bank-specific and macroeconomic indicators. This finding implies that other factors outside the bank and economic indicators outside the scope of this study may account for the remaining $64.2 \%$ of variations. Those factors may include the quality of management, the 
credit risk management control system, borrowers' characteristics and political factors. The study is only limited to the listed deposit money banks in Nigeria, while the non-deposit money banks were not considered. This is the major limitation of the study. Thus, the study contributes to the finance literature due to the investigation performed in it of how bankspecific and macroeconomic indicators influence the nonperforming loans of the Nigerian deposit money banks. The study established a significant joint effect of both bank-specific and macroeconomic determinants on nonperforming loans. The findings, however, indicated the fact that the bank-specific variables (such as profitability, capital adequacy, age, the loans-to-total-assets ratio and the size) are the major factors that influence nonperforming loans in the Nigerian deposit money banks.

Based upon these findings, the study suggests and recommends that banks' finance managers and top management should take cognizance of profitability, capital, age, the loans-to-total-assets ratio and the size in making attempts to reduce nonperformance loans. Also, they should take into account the prevailing economic conditions while making decisions involving loan administration. The government should make and implement the economic policies that will improve the banks' ability to reduce the efficacy of nonperforming loans through a proper control of the inflation and interest rates.

The study clearly shows the importance of the bankspecific variables for the nonperforming loans of the Nigerian listed deposit money banks. This outcome encourages banks to properly manage their credit risk by taking into consideration liquidity, capital adequacy, the loans-to-total-assets ratio and the size in their attempts to reduce nonperforming loans.

The study is limited to the sample of a total of 10 banks for the period from 2008 to 2017. Future research efforts should increase the timeframe of the study by taking into consideration a larger number of years, as well as the other factors that may have an influence on nonperforming loans, most especially so from the borrower's perspective. Future research efforts should also be directed towards other, non-deposit money banks.

\section{REFERENCES}

Agnello, L., \& Sousa, R. M. (2012). How do banking crises impact on income inequality? Applied Economics Letters. Taylor \& Francis Journals, 19(15), 1425-1429. doi:10.1080/1350 4851.2011.631885

Akerlof, G. A. (1970). The market for "lemons": Quality uncertainty and the market mechanism. The quarterly journal of economics, 84(3), 488-500.

Akinlo, O., \& Mofoluwaso, E. (2014). Determinants of nonperforming loans in Nigeria. Accounting \& Taxation, 6(2), 21-28.

Allen, F., \& Santomero, A. M. (1997). The theory of financial intermediation. Journal of Banking and Finance, 21(11-12), 1461-1485. doi.org/10.1016/S0378-4266(97)00032-0

Alshatti, A. S. (2015). The effect of credit risk management on financial performance of Jordanian commercial banks. Investment Management and Financial Innovations, 12(1-2), 338-345.

Awour, F. O. (2015). Impacts of military training on the distribution and abundance of small versus large wildlife herbivores on Mpala Ranch, Laikipia, Kenya. African Journal of Ecology, 53(2), 238-241. doi.org/10.1111/aje.12210

Basel Committee on Banking Supervision. (2001). Risk Management Practices and Regulatory Capital: Cross-Sectional Comparison. Retrieved October 12, 2019 from https://www. bis.org/publ/joint04.pdf

Chabakauri, G., \& Han, B. Y. (2016). Capital Requirements and Asset Prices. Retrieved September 14, 2019 from http://ssrn. com/ abstract $=2689672$ doi:10.2139/ssrn. 2689672

Diamond, D. (1984). Financial intermediation and delegated monitoring. Review of Economic Studies, 51(3), 393-414. doi:10.2307/2297430

Djiogap, C. F., \& Ngomsi, A. (2012). Determinants of bank long term lending behavior in the Central African Economic and Monetary Community (CEMAC). Review of Economics and Finance, 2, 107-114.

Duong, N. T., \& Huong, T. T. (2016). The analysis of major credit risk factors - The case of the Vietnamese commercial banks. International Journal of Financial Research, 8(1), 33-42. doi:10.5430/ijfr.v8n1p33 
Gambo, EL-M. J., Ahmad, A-R., Muhammad, I. (2017). Determinants of non-performing loans in Nigerias deposit money banks. Archives of Business Research, 5(1), 74-88. doi. org/10.14738/abr.51.2368

Gennaioli, N., Shleifer, A., \& Vishny, R. W. (2013). A model of shadow banking. The Journal of Finance, 68(4), 1331-1363. doi. org/10.1016/j.jfinecofi.12031

Ikram, A., Su, Q., Ijaz, F., \& Fiaz, M. (2016). Determinants of non-performing loans: An empirical investigation of bankspecific microeconomic factors. Journal of Applied Business Research, 32(6), 1723-1736. doi.org/10.19030/jabr.v32i6.9819

Kajola, S. O., Adedeji, S. B., Olabisi, J., \& Babatolu, A. B. (2018). Effect of credit risk management on financial performance of Nigerian listed deposit money banks. Scholedge International Journal of Business Policy \& Governance, 5(6), 5362. doi:10.19085/journal.sijbpg050601

Kasana, S. I., \& Naveed, Q. M. (2016).The determinants of credit risk in commercial banks of Pakistan. Journal of Poverty, Investment and Development, 26, 65-72.

Koju, M., Koju, R., \& Wang, S. (2018). Does banking management affect credit risk? Evidence from the Indian banking system. International Journal of Financial Studies, 67(6), 1-11. doi.org/10.3390/ijfs6030067

Louziz, P. D., Vouldis, A. T., \& Metaxas, V. L. (2012). Macroeconomic and bank-specific determinants of nonperforming loans in Greece: A comparative study of mortgage, business and consumer loan portfolios. Journal of Banking \& Finance, Elsevier, 36(4), 1012-1027. doi:10.1016/j. jbankfin.2011.10.012

Makri, V., \& Papadatos, K. (2014). How accounting information and macroeconomic environment determine credit risk: Evidence from Greece. International Journal of Economic Sciences and Applied Research, 7(1), 129-143.

Matthews, K., \& Thompson, J. (2008). The Economics of Banking. Chichester, UK: Wiley.

Messai, A. S., \& Jouini, F. (2013). Micro and macro determinants of non-performing loans. International Journal of Economics and Financial Issues, 3(4), 852-860.

Mpofu, T. R., \& Nikolaidou, E. (2018). Determinants of credit risk in the banking system in Sub-Saharan Africa. Review of Development Finance, 8(2), 141-153. doi.org/10.1016/j. rdf.2018.08.001
Murthy, U., Kamil, N. M., Mariadas, P. A., \& Devi, D. (2017). Factors influencing non-performing loans in commercial banks: The case of banks in Selangor. International Journal of Business and Management, 12(2), 246-255. doi:10.5539/ijbm. v12n2p246

Okere, W., Isiaka, M. A., \& Ogunloworo, A. J. (2018). Risk management and financial performance of deposit money banks in Nigeria. European Journal of Business, Economics and Accountancy, 6(2), 30-42.

Psillaki, M., Tsolas, I. E., \& Margaritis, D. (2010). Evaluation of credit risk based on firm performance. European Journal of Operational Research, 201(3), 873-881. doi:10.1016/j. ejor.2009.03.032

Rajha, K. S. (2017). Determinants of non-performing loans: Evidence from the Jordanian banking sector. Journal of Finance and Bank Management, 5(1), 54-65. doi:10.15640/jfbm. v5n1a5

Ranjan, R., \& Dhal, S. C. (2003). Non-performing loans and terms of credit of public sector banks in India: An empirical assessment. Reserve Bank of India Occasional Papers, 24(3), 81121.

Ratnovski, L. (2012). Banking and Trading. Working paper No. 238. Washington, DC: International Monetary Fund.

Salas, V., \& Saurina, J. (2002). Credit risk in two institutional regimes: Spanish commercial and savings banks. Journal of Financial Services Research, 22(3), 203-224. doi:10.1023/A:1019781109676

Saba, I., Kouser, R., \& Azeem, M. (2012). Determinants of nonperforming loans: Case of US banking sector. The Romanian Economic Journal, 15(44), 125-136.

Skarica, B. (2013). Determinants of non-performing loans in Central and Eastern European countries. Working Paper.

Shkodra, J., \& Ismajli, H. (2017). Determinants of the credit risk in developing countries: A case of Kosovo banking sector. Banks and Bank Systems, 12(4), 90-97.

Shleifer, A., \& Vishny, R. W. (2010). Unstable banking. Journal of Financial Economics, 97(3), 306-318. doi.org/10.1016/j. jfineco.2009.10.007

Stiglitz, J. E., \& Weiss, A. (1981). Credit rationing in markets with imperfect information. The American Economic Review, 71(3), 393-410. 
Swamy, V. (2012). Impact of macroeconomic and endogenous factors on nonperforming bank assets. International Journal of Banking and Finance, 9(1), 27-47. doi:10.2139/ssrn.2060753

Trenca, L., \& Bozga, D. (2018). Determinants of credit risk in the European banking sector. Euro Economica, 37(1), 108-113.

Yuksel, S., Mukhtarov, S., \& Mammadov, E. (2016). Comparing the efficiency of Turkish and Azerbaijani banks: An application with data envelopment analysis. International Journal of Economics and Financial Issues, 6(3), 1059-1067.
Waemustafa, W., \& Sukri, S. (2015). Bank specific and macroeconomics dynamic determinants of credit risk in Islamic banks and conventional banks. International Journal of Economics and Financial Issues, 5(2), 476-481. doi:10.6084/ m9.figshare.4042992

\section{Received on $16^{\text {th }}$ December 2019, after revision, accepted for publication on $13^{\text {th }}$ April 2020 \\ Published online on $24^{\text {th }}$ April 2020}

Sanyaolu Wasiu Abiodun is a lecturer at the Department of Accounting, Crescent University, Abeokuta. He holds MSc in Accounting from Crescent University, Abeokuta and MSc in Finance from Olabisi Onabanjo University, Ago-Iwoye. He is an Associate member of the Institute of Chartered Accountants of Nigeria. His research interest includes auditing and assurance, financial reporting, financial management and macroeconomics.

Shiyanbola Trimisiu Tunji is a Senior Lecturer at the Department of Accounting, Babcock University, Ilisan Remo. He has PhD in Accounting from Babcock University, Ilisan Remo. He is a fellow of the institute of Chartered Accountants of Nigeria. His research interest includes financial management and corporate governance issues, banking, corporate reporting, financial reporting and ethics and auditing.

Makinde Afeez Babatunde is in the department of Business and Administration, Crescent University. He has MSc in Business Administration from Olabisi Onabanjo University, Ago- Iwoye. His research interest is management. 


\title{
KARAKTERISTIKE LOŠIH ZAJMOVA DEPOZITNIH BANAKA U NIGERIJI
}

\author{
Wasiu Abiodun Sanyaolu', Trimisiu Tunji Siyanbola² and Hafeez Babatunde Makinde \\ 'Department of Accounting, Crescent University, Abeokuta, Ogun State, Nigeria \\ ${ }^{2}$ Department of Accounting, Babcock University, llishan Remo, Ogun State, Nigeria \\ 3Department of Business and Finance, Crescent University, Abeokuta, Ogun State, Nigeria
}

\begin{abstract}
Kreditni rizik predstavlja jedan od najvećih izazova sa kojima se suočavaju banke u Nigeriji. Implicitno, on predstavlja izazov koji ima pogubne posledice po njihovo poslovanje i opstanak, jer je čitav niz problema u poslovanju banaka značajno povezan sa lošim zajmovima. Stoga, u ovoj studiji se ispituju bankovno specifične i makroekonomske odrednice loših zajmova, u ovom slučaju loših zajmova depozitnih banaka (DB) u Nigeriji. U ovoj studiji primenjena je regresiona analiza, koja uključuje fiksni učinak, u cilju analize panel podataka 10 izabranih depozitnih banaka, u periodu 2008- 2017. Rezultati do kojih se došlo pokazuju da racio adekvatnosti kapitala, veličina i racio zajmova u odnosu na ukupnu aktivu banaka negativno i značajno utiču na loše zajmove, dok, s druge strane, profitabilnost i godište značajno, ali pozitivno, utiču na loše zajmove depozitnih banaka u Nigeriji. Štaviše, racio likvidnosti negativno, ali beznačajno, utiče na loše zajmove. Međutim, nijedna od makroekonomskih varijabli ne utiče značajno na loše zajmove. U studiji se daju preporuke u smislu da bi banke uvek trebalo da razvijaju strategije za upravljanje kreditnim rizikom, uzimajući u obzir bankovno specifične i ekonomske odrednice loših zajmova odobrenih od strane banaka.
\end{abstract}

Ključne reči: specifični pokazatelji banaka, depozitne banke, makroekonomski pokazatelji, fiksni učinak i loši zajmovi 